\title{
Size at onset of sexual maturity and onset of spawning in female Panulirus homarus (Crustacea: Decapoda: Palinuridae) in Sri Lanka
}

\author{
D. S. Jayakody* \\ National Aquatic Resources Agency, Crow Island, Mattakkuliya, Colombo 15, Sri Lanka
}

\begin{abstract}
The average length at which female spiny lobsters Panulirus homarus attain sexual maturity was determined in Sri Lanka from 1986 to 1988 by observing changes in length of the tail, which later provides the substratum for attachment of fertilized eggs. Results were confirmed by observing the presence of spermatophores on the females' sternum. The size at onset of oviposition (spawning) was estimated by considering the $50 \%$ ovigerous level. Results indicate that female $P$. homarus attain sexual (gonad) maturity after a rostral carapace length (RCL) of between 38 and $47 \mathrm{~mm}$ is reached. The size at onset of oviposition (spawning) was estimated as $59.5 \mathrm{~mm} \mathrm{RCL}$.
\end{abstract}

\section{INTRODUCTION}

The onset of sexual maturity in female spiny lobsters can be determined by the presence of several externally visible features, viz. well-developed pleopod endopodal setae (Street 1969, Pollock \& Augustyn 1982), presence of spermathecae (Munro 1974, Morizur 1983), and presence of externally attached eggs (Kensler 1967). Both Fielder (1964) and Morizur (1983) noted the state of ovary development as a feature and Templeman $(1935,1944)$ demonstrated that abdomen width in female homarid lobsters increased relative to body total length at sexual maturity. George \& Morgan (1979) noted external elongation of the anterior pairs of walking legs of Panulirus versicolor corresponding with onset of maturity.

Many authors have used the '50\% maturity level' (i.e. the smallest carapace length at which $50 \%$ of a population bears eggs) as an index of maturity and breeding, although studies by Chittleborough (1976) on Panulirus longipes and by Booth (1984) on Jasus verreauxi demonstrated a delay between the appearance of pleopod setae and spawning. At least 2 interconnected physiological changes appear to govern the changes associated with sexual maturity and the onset

\footnotetext{
- Present address: Scottish Marine Biological Association, Dunstaffnage Marine Research Laboratory, PO Box 3, Oban Argyll, PA34 4AD, Scotland
}

of oviposition (spawning). By itself the 50\% maturity criterion can be misleading unless size at spawning is also considered. In this study the relationship is examined between carapace and abdomen (tail) lengths and the presence of eggs of the spiny lobsters Panulirus homarus (L.), to determine sizes at which changes occur associated with sexual maturity and onset of oviposition (spawning).

\section{MATERIALS AND METHODS}

Lobster landing sites along the south coast of Sri Lanka were visited fortnightly from 1986 to 1988 and all the lobsters Panulirus homarus landed by randomly selected boats on a particular day were measured at the landing site. Lobsters were handled in fresh condition and length measurements were made to the nearest mm using a measuring board. The sex of each specimen was recorded and other information for female lobsters, such as the presence of spermatophores and eggs, was recorded.

Carapace length (standard length) was measured in the mid dorsal line from the anterior end of the rostral horns to the posterior margin of the carapace. Lobsters with regenerating horns were not included in this analysis. Rostral carapace length (RCL) values were plotted against tail length values for males and females separately. The steps used in this analysis were the 
same as those used by George \& Morgan (1979) and Grey (1979) in their intersect analysis. The resulting plots were examined visually for discontinuities in the slopes of the regressions. Least squares regressions were fitted separately to immature males and females, mature males and mature females. Student's $t$-test was used to determine the validity of the slopes of regression lines. The value of the intersect of the 2 regression lines (mature males and mature females) was calculated for carapace and tail length data for which a significant difference in slope of the 2 regression lines was observed. As there was no statistically significant difference in the slopes of the regression lines of immature males and females, the data were combined to construct a single regression line.

\section{RESULTS}

\section{Carapace length/total length and tail length relations}

The fitted regression lines for the relations between RCL and total length values for male and female Panulirus homarus are shown in Fig. 1.

Carapace length and tail length values were also plotted (Fig. 2), and 3 regression lines were considered: (1) for immature lobsters of both sexes (below $35 \mathrm{~mm}$ $\mathrm{RCL}$ ); (2) for mature males (over $50 \mathrm{~mm} \mathrm{RCL);} \mathrm{(3)} \mathrm{for}$ mature females (over $50 \mathrm{~mm}$ RCL).

In fitting regressions, lengths were taken in $\mathrm{cm}$. Regression equations and other relevant data are summarised in Table 1.

The carapace length vs total length plot (Fig. 1) shows a similarity in growth patterns in males and females in the early stages, but later in life, females become longer than males. When the carapace length vs tail length plot is considered (Fig. 2), the female abdomen is seen to grow faster in length than that of the male in later life. This phenomenon is considered to be an adaptation to bear eggs once they are fertilised, and the inflection point is used here as a measure of size at first sexual maturity. According to Fig. 2, the female has a longer tail than the male above a size of about $38 \mathrm{~mm}$ RCL. (As in Templeman [1935] and

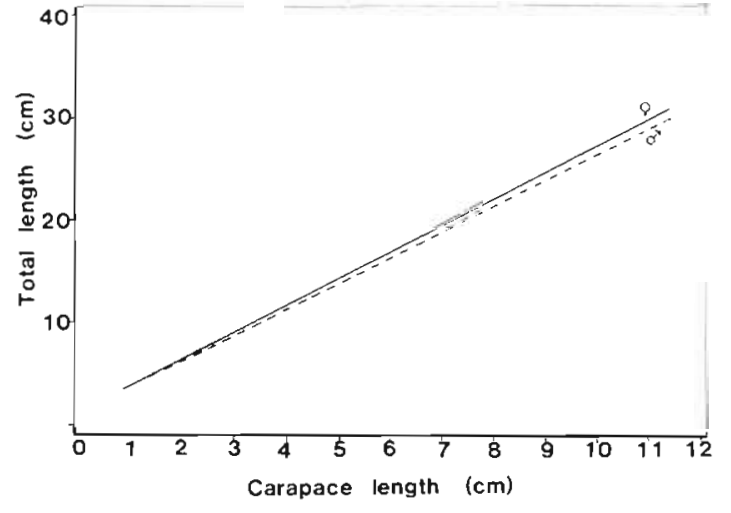

Fig. 1. Panulirus homarus. Fitted regression lines for total length and carapace length relationship for males and females collected from the south coast of Sri Lanka

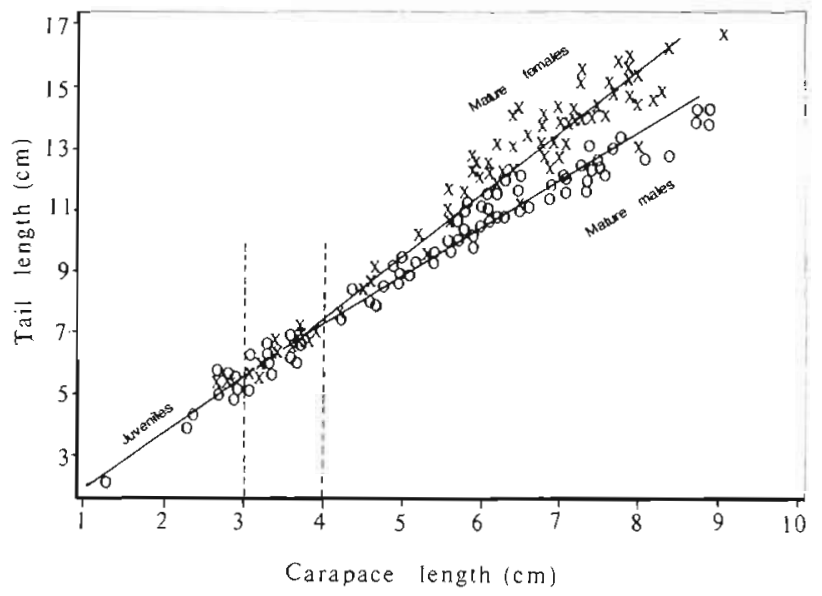

Fig. 2. Panulirus homarus. Fitted regression lines for carapace length and tail length of males (O) and females (X). Dotted lines show intersect area and 'point of upturn'

George \& Morgan [1979], the inflection point [Fig. 2] has been estimated by eye.)

\section{Spermatophore formation}

Females with spermatophores were observed throughout the year but the smallest individual females bearing spermatophores were observed in October

Table 1. Panulirus homarus. Summary of regressions describing relationships between rostral carapace length (RCL)/total length (Lto) and RCL/tail length (Lt1) for males and females

\begin{tabular}{|c|c|c|c|c|c|c|}
\hline Sex & $x$ & Y & Regression equation & $N$ & r & Prob $>F$ \\
\hline Male & RCL & Ito & $Y=1.3146+2.5158 X$ & 320 & 0.9904 & 0.0001 \\
\hline Female & $\mathrm{RCL}$ & Lto & $Y=1.3582+2.5982 X$ & 376 & 0.9736 & 0.0001 \\
\hline Immature male/female & $\mathrm{RCL}$ & Lt] & $Y=0.2353+1.7657 X$ & 22 & 0.8657 & 0.0001 \\
\hline Mature male & RCL & Lt] & $Y=1.0231+1.5646 X$ & 47 & 0.9664 & 0.0001 \\
\hline Mature female & RCL & Lti & $Y=-0.0938+1.9528 X$ & 53 & 0.9539 & 0.0001 \\
\hline
\end{tabular}


Table 2. Panulirus homarus. Summary of linear measurements, spermatophore and egg condition of the 2 smallest females observed during the study. Lto: total length; Ltl: tail length; RCL: rostral carapace length

\begin{tabular}{|lccccc|}
\hline $\begin{array}{l}\text { Female } \\
\text { no. }\end{array}$ & $\begin{array}{c}\text { Lto } \\
(\mathrm{mm})\end{array}$ & $\begin{array}{c}\text { Ltl } \\
(\mathrm{mm})\end{array}$ & $\begin{array}{c}\text { RCL } \\
(\mathrm{mm})\end{array}$ & & \\
\hline 1 & 136 & 89 & 47 & White & Bright orange \\
2 & 133 & 85 & 47 & White & Bright orange \\
\hline
\end{tabular}

1986 and November 1987. Detailed observations on these 2 females are summarised in Table 2.

The external appearance of the spermatophores indicated that the females had scraped the outer hard cover of the spermatophores to release sperms for fertilization. The presence of orange eggs further supported this observation and indicated recent fertilization. The presence of ovigerous females with spermatophores at a rostral carapace length of $47 \mathrm{~mm}$ indicates that they had attained sexual maturity at a much smaller size (possibly $10 \mathrm{~mm}$ or more smaller RCL), in agreement with the present value of $38 \mathrm{~mm}$ RCL estimated from the RCL/tail length studies for the onset of maturity in the female.

\section{Size at onset of spawning}

Females encountered during the study period could be broadly categorised into 2 carapace length groups, and for each the presence or absence of spermatophores and eggs was noted. Results are shown in Table 3.

These results indicate that the majority of females bear spermatophores and eggs after attaining a size of $50 \mathrm{~mm}$ RCL. To more closely assess size at onset of breeding, the RCL group from 50 to $60 \mathrm{~mm}$ was considered in detail and results are shown in Table 4. These data indicate that a smaller percentage $(<10 \%)$ of first-time spawners are fertilized at a size of 50 to $55 \mathrm{~mm}$ than at 56 to $60 \mathrm{~mm}$ RCL.

\section{Size at $50 \%$ ovigerous}

Numbers of females bearing extrenally visible eggs in different length groups are given in Table 5.

Percentage maturity values were plotted against the mid length values of the each RCL group on probability paper (Wenner et al. 1974), and the results are shown in Fig. 3. This technique suggests a value of $59.5 \mathrm{~mm} \mathrm{RCL}$ for $50 \%$ ovigerous level, which corresponds to size at onset of spawning.

\section{DISCUSSION}

Size at onset of sexual maturity and spawning are important biological characters that can be used in the management of exploited lobster stocks for determin-

Table 3. Panulirus homarus. Summary of 2 broad categories $(0$ to $50 \mathrm{~mm}$ and 51 to $100 \mathrm{~mm}$ RCL) of females bearing spermatophores and eggs

\begin{tabular}{|c|c|c|c|c|}
\hline $\begin{array}{l}\mathrm{RCL} \\
(\mathrm{mm})\end{array}$ & $\begin{array}{c}\% \text { without spermatophores } \\
\text { and eggs }\end{array}$ & $\begin{array}{c}\% \text { with spermatophores } \\
\text { but no eggs }\end{array}$ & $\begin{array}{c}\% \text { with spermatophores } \\
\text { and eggs }\end{array}$ & $N$ \\
\hline $0-50$ & 98.4 & 0.00 & 1.60 & 91 \\
\hline $51-100$ & 26.12 & 17.83 & 56.05 & 285 \\
\hline
\end{tabular}

Table 4. Panulirus homarus. Summary of 2 narrow categories (50 to $55 \mathrm{~mm}$ and 56 to $60 \mathrm{~mm} \mathrm{RCL}$ ) of females bearing spermatophores and eggs

\begin{tabular}{|lccc|}
\hline $\begin{array}{l}\mathrm{RCL} \\
(\mathrm{mm})\end{array}$ & $\begin{array}{c}\text { \% without spermatophores } \\
\text { and eggs }\end{array}$ & $\begin{array}{c}\text { \% with spermatophores } \\
\text { but no eggs }\end{array}$ & $\begin{array}{c}\text { \% with spermatophores } \\
\text { and eggs }\end{array}$ \\
\hline $50-55$ & 85.72 & 5.71 & 8.57 \\
$56-60$ & 71.43 & 7.14 & 21.43 \\
\hline
\end{tabular}

Table 5. Panulirus homarus. Summary of percentage maturity values of females in each $5 \mathrm{~mm}$ RCL size class

\begin{tabular}{|lccccccccc|}
\hline & \multicolumn{1}{c|}{ Length group (RCL, mm) } & & & \\
& $40-45$ & $46-50$ & $51-55$ & $56-60$ & $61-65$ & $66-70$ & $71-75$ & $76-80$ & $81-85$ \\
\hline Percentage maturity & 0.0 & 1.61 & 11.0 & 44.1 & 58.5 & 80.0 & 100.0 & 94.7 & 100.0 \\
\hline
\end{tabular}




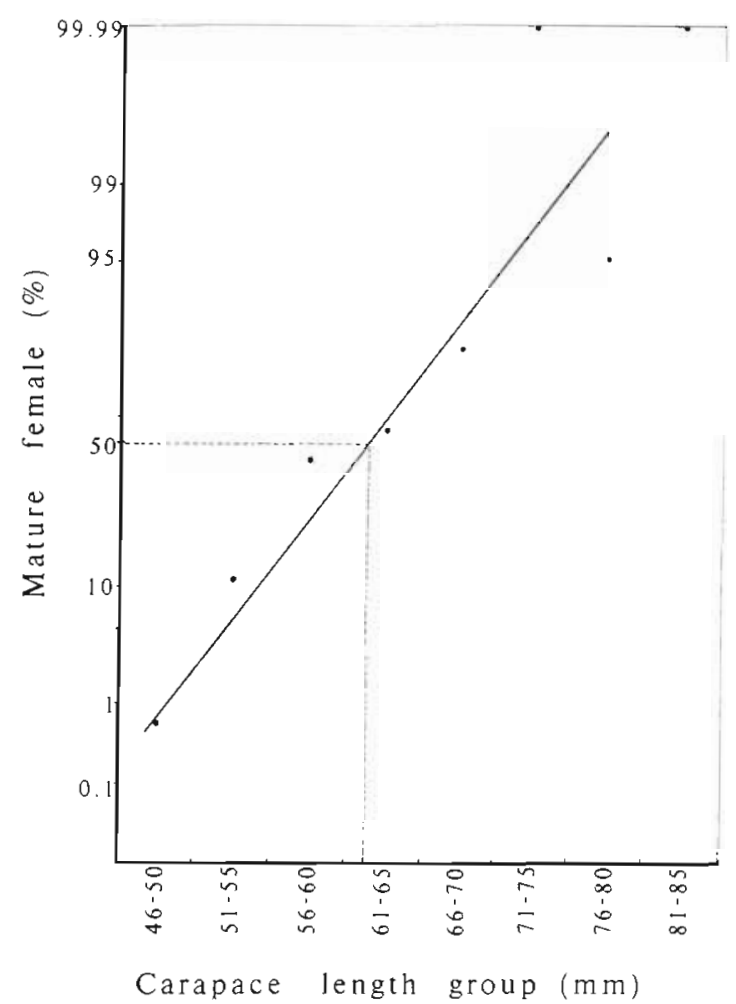

Fig. 3. Panulirus homarus. Percentage of female spiny lobsters in each $5 \mathrm{~mm}$ rostral carapace length size class which were mature. This illustrates the probability paper technique for estimating size at onset of breeding

ing a suitable minimum legal size (Annala et al. 1980, Booth 1984).

External secondary sexual features, such as the presence of ovigerous setae, a spermatophoric mass or external eggs, are those commonly in use for the determination of the size at first physical maturity of female lobsters. Of these features, the smallest carapace length at which $50 \%$ have mated (generally known as $50 \%$ maturity) is the most usually used. Information on the size at first maturity of male lobsters is generally lacking. Heydorn $(1965,1969)$ concluded from his work on rock lobsters that testis examination does not provide accurate resuits and therefore gives no reliable indications of stages in the reproductive cycle. Berry (1970) and George \& Morgan (1979) observed the extreme elongation of frontal walking legs (especially 2nd and 3rd) during the period of physical maturity and suggested that this can be used to estimate the size at first physical maturity of males. Heydorn (1969) showed that the smallest sexually mature female Panulirus homarus observed had a carapace length of $43 \mathrm{~mm}$ in South African waters. Heydorn further suggested that it is possible to assume that the female population as a whole can be regarded as being sexually mature in the research area at a carapace length of
$50 \mathrm{~mm}$ and more. Berry (1970), working in South African waters, concluded that the majority of females were mature at 54 to $60 \mathrm{~mm}$ carapace length. Where Sri Lankan waters are concerned, De Bruin (1962) suggested that Panulirus dasypus (later named Panulirus homarus) reach a length of 55 to $59 \mathrm{~mm}$ carapace length with the onset of maturity.

Booth's (1984) data on Jasus verreauxi indicated that there is a delay between the first development of ovigerous setae and the bearing of eggs, and further concluded that most females develop eggs at a carapace length $10 \mathrm{~mm}$ or more greater than that at which they first develop setae. It is seen from the present study that the graphs for males and females (Fig. 2) overlap up to $38 \mathrm{~mm}$ RCL, after which there is a distinct separation of regression lines. It should be noted that the smallest ovigerous females were found with RCL $47 \mathrm{~mm}$. The overlapping of the graphs at RCL $38 \mathrm{~mm}$ might be attributed to the minimum size of the starting of gonad maturity. The separation of the graphs after $38 \mathrm{~mm}$ on the other hand might be due to a differential relative growth pattern between the 2 sexes. The total length vs RCL plot for both sexes (Fig. 1) also indicates a slow and gradual trend of higher growth of females relative to males with size, but from the tail length vs RCL plot (Fig. 2), the elongation of the tail of females seems to be very marked after $38 \mathrm{~mm}$ RCL. This is throught to be an adaptation of female Panulirus homarus to provide a suitable surface area under the tail for incubation of eggs after fertilization has taken place. The results obtained in this study indicate that, similar to the intersect method, linear regression analysis of carapace and tail length data can be used to differentiate juvenile from adult $P$. homarus. The estimate made, based on the ' $50 \%$ ovigerous' level using the probability paper method, provides clues about size at onset of breeding and corresponds to a RCL value of $59.5 \mathrm{~mm}$, a slightly higher estimate than that of De Bruin (1962). De Bruin's estimate of size at first maturity of $P$. homarus was based on data from the west coast of Sri Lanka, whereas estimates in the present study are based on data collected from the south coast. Differences in size at first maturity between localities are known to exist in several spiny lobster species (Matthews 1962, Heydorn 1965, Street 1969, Annala et al. 1980). Size at first maturity values estimated for $P$. homarus in different regions are shown in Table 6 .

In the present study, 'size at first maturity' was estimated by using 3 different methods: (1) the tail length vs RCL plot; (2) observations on smallest females with spermatophoric mass and eggs; and (3) '50\% ovigerous' level using the probability paper technique. When the Panulirus homarus population is considered as a whole, the first 2 methods suggest values of 38 to 
Table 6. Panulirus homarus. Size at first maturity of females from different regions of the world. CL: carapace length

\begin{tabular}{|lll|}
\hline Location & Size at first sexual maturity & Source \\
\hline South coast of Sri Lanka & $38-47 \mathrm{~mm} \mathrm{CL}$ & This study \\
West coast of Sri Lanka & $(59.5 \mathrm{~mm} \mathrm{for} \mathrm{oviposition} \mathrm{[spawning])}$ & De Bruin (1962) \\
East Aden & $55-59 \mathrm{~mm} \mathrm{CL}$ & George (1963) \\
South Africa, Transkeian waters & $60-70 \mathrm{~mm} \mathrm{CL}$ & Heydorn (1969) \\
South Africa, Natal waters & $50 \mathrm{~mm} \mathrm{CL}$ & Berry (1971) \\
\hline
\end{tabular}

$47 \mathrm{~mm}$ RCL for size at onset of first sexual (gonad) maturity and the third method suggests a value of $59.5 \mathrm{~mm}$ RCL for size at onset of first physical maturity or spawning (oviposition).

Although the intersect method suggested a value for first physical maturity (George \& Morgan 1979. Grey 1979) (using carapace length vs leg length) the present study revealed that carapace length and tail length data can be used to estimate a value for the first sexual (gonad) maturity.

Acknowledgements. This manuscript was reviewed by Dr D. S. McLusky (University of Stirling, Scotland) and Dr A. Ansell (Dunstaffnage Marine Research Laboratory, Scotland). I am grateful for their criticisms and suggestions. Special thanks are due to Dr C. B. Kensler (FAO/UNDP), for his helpful advice during the field visits and also to Mr H. A. R. E. Perera for his assistance given in the field work. Finally I thank anonymous referees who provided substantive comments to improve the quality of this paper. This research was supported by the National Aquatic Resources Agency, Sri Lanka.

\section{LITERATURE CITED}

Annala, J. H., Mckoy, J. D., Booth, J. D., Pike, R. B. (1980) Size at the onset of sexual maturity in female Jasus edwardsii (Decapoda: Palinuridae) in New Zealand. N. Z. Jl mar Freshwat. Res. 14: 217-227

Berry, P. F. (1970). Mating behaviour, oviposition and fertilization in the spiny lobster Panulirus homarus (L.). Investl Rep. Oceanogr. Res. Inst. S. Afr 24: 1-16

Berry, P. F. (1971). The biology of the spiny lobster, Panulirus homarus (L.) off the east coast of South Africa. Investl Rep. Oceanogr. Res. Inst. S. Afr. 28: 1-76

Booth, J. D. (1984). Size at onset of breeding in female Jasus verreauxi (Decapoda: Palinuridae) in New Zealand. N. Z. $\mathrm{Jl}$ mar. Freshwat. Res. 18: 159-169

Chittleborough, R. G. (1976). Breeding of Panulirus longipes cygnus George under natural and controlled conditions. Aust. J. mar. Freshwat. Res. 27: 499-516

De Bruin, G. H. P. (1962). Spiny lobsters of Ceylon. Bull. Fish. Res. Stn Ceylon 14: 1-28

Fielder, D. B. (1964). The spiny lobster Jasus lalandii (H. Milne Edwards), in South Australia. 11. Reproduction. Aust. J. mar. Freshwat. Res. 15: 133-144

George, R. W. (1963). Crawfish resources of Eastern Aden

This article was presented by Dr D. S. McLusky, Stirling, Scotland
Protectorate. FAO Expanded Prog. of Tech. Assistance Rep. No. 1696: 1-23

George, R. W., Morgan, G. R. (1979). Linear growth stages in the rock lobster (Panulirus versicolor) as a method for determinating size at first physical maturity. Rapp. P.-v. réun. Cons. int. Explor. Mer 175: 182-185

Grey, K. A. (1979). Estimates of the size at first maturity of the western rock lobster, Panulirus cygnus, using secondary sexual characteristics. Aust. J. mar. Freshwat. Res. 30: 785-791

Heydorn, A. E. F. (1965). The rock lobster of the South African West coast Jasus lalandii (H. Milne Edwards) 1. Notes on the reproductive biology and the determination of minimum size limits for commercial catches. Investl Rep. Div. Sea Fish. S. Afr. 53: 1-32

Heydorn, A. E. F. (1969). Notes on the biology of Panulirus homarus and on length/weight relationship of Jasus lalandii. Invest] Rep. Div. Sea Fish. S. Afr 69: 1-19

Kensler, C. B. (1967). Size at first maturity in females of the spiny lobster Jasus verreauxi (Crustacea:Decapoda: Palinuridae). N. Z. Jl mar Freshwat. Res. 1: 327-340

Matthews, J. P. (1962). The rock lobster of South West Africa, Jasus lalandii (Milne-Edwards). Size frequency, reproduction, distribution and availability. Investl Rep. mar Res. Lab. S. W. Afr. 7: 1-66

Morizur, Y (1983). Utilisation de critères fonctionnels (presence de spermatophore, maturation des ovaries) pour la determination de la taille et de l' âge à maturité sexuelle des Nephrops norvegicus femelles de la région sud-Bretagne. J. Cons. int. Explor Mer 41: 28-36

Munro, J. L. (1974). The biology, ecology, exploitation and management of Caribbean reef fishes. Scientific report of the ODA/UNI fisheries ecology research project, 1962-1973. Part 6. The biology, ecology and bionomics of Caribbean reef fishes - Crustaceans (spiny lobsters and crabs). Univ. West Indies, Zool. Dep. Res., Rep. 3: 1-57

Pollock, D. E., Augustyn, C. J. (1982). Biology of the rock lobster Palinurus gilchristi with notes on the South African fishery. Fish. Bull. S. Afr. 16: 57-73

Street, R. J. (1969). The New Zealand crayfish, Jasus edwardsii (Hutton 1875). N. Z. Mar. Dept. Fish. Tech. Rep. 30: 1-53

Templeman, W. (1935). Local differences in the body proportions of the lobster Homarus americanus. J. biol. Bd Can. 1: 213-226

Templeman, W. (1944). Abdominal width and sexual maturity of the female lobsters on Canadian Atlantic Coast. J. Fish. Res. Bd Can. 6: 281-290

Wenner, A. M., Fusaro, C., Oaten, A. (1974). Size at onset of sexual maturity and growth rate in crustacean populations. Can. J. Zool. 52: 1095-1106

Manuscript first received: January 20,1989

Revised version accepted: May 11, 1989 